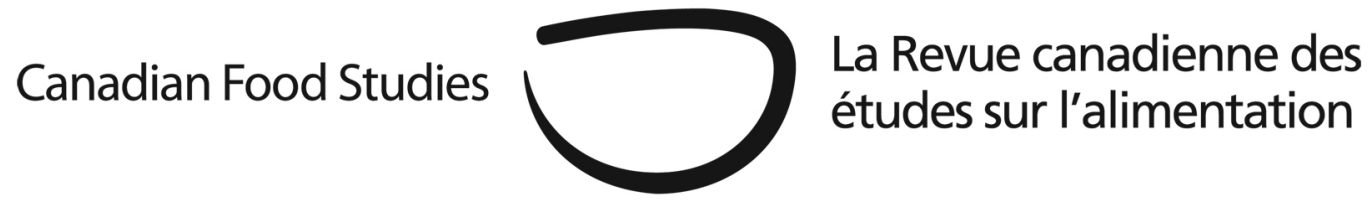

Original Research Article

\title{
Farm stores in agriburbia: The roles of agricultural retail on the rural-urban fringe
}

\author{
Lenore Newman ${ }^{a *}$, Lisa Jordan Powell ${ }^{b}$, Jennifer Nickelc, Dylan Andersonc, Lea \\ Jovanovicc, Eileen Mendezc, Barbara Mitchellc, Kathryn Kelly-Freibergc
}

${ }^{a}$ Associate Professor, Department of Geography and Environment, University of the Fraser Valley bPostdoctoral scholar, Faculty of Land and Food, University of British Columbia

'University of the Fraser Valley

\begin{abstract}
This investigation highlights the role of on-farm stores on the rural-urban fringe near Abbotsford, British Columbia, Canada. Farming near a large urban centre was found to create opportunities for higher returns such as marketing of local food and-agritourism. However existence of farming near urban areas depends on higher returns and a supportive public. Longitudinal case study of four farm stores operating nearly year round within the Agricultural Land Reserve revealed that the farm stores catered to a rural idyll that reflects cultural conceptions of farm life. We suggest the multifunctional landscape of the farm store provides economic and cultural benefits, and should be considered as sustaining agriculture. However operators must shape their offerings according to a dialectic with the non-farming public who have strong expectations of the farm experience. The study revealed that farm store operators in particular share the rural idyll of urban consumers, though agritourism operators are more consciously including rural elements in their operations. Though multifunctionality was a choice, it was influenced by the customer base and created its own challenges and costs.
\end{abstract}

Keywords: Rural-urban fringe, farm retail, agriburbia, agritourism, multifunctionality, local food, agricultural land reserve, rural idyll

*Corresponding author: Lenore.Newman@ufv.ca

DOI: $10.15353 /$ cfs-rcea.v4i1.211

ISSN: 2292-3071 


\section{Introduction and literature review}

The rural-urban fringe is a site of rapidly changing and highly diverse landscapes, where industrial, residential, and agricultural land uses come together along complicated borderlands. The transition from city to countryside is a critical interface where different aspects of human activity coexist. Food production is one critical element of this landscape; MacDonald and Keil (2012), for example, discuss the long role of the suburb as a source of fresh produce and protein for the city. The pattern of such production can be understood in spatial terms that have changed little since the work of von Thünen (1966), who explained the geographical distribution of food production near cities; high value and perishable crops such as dairy were closest to urban markets, and less valuable row crops moved to the hinterlands as populations rose. In short, land cost near cities ensures that farms are small, and production diverse and intensive.

Despite the globalization of food chains, the rural-urban fringe is still the site of robust food production. As Jackson-Smith, Clark, Sharp, and Inwood (2008) note in the American context, counties on the rural-urban interface produce twice the farm gate sales as those counties located farther from urban areas. However loss of farmland to urban sprawl is a major challenge in most areas of the rural-urban fringe (See Nixon and Newman (2016) for a local overview) In the Canadian context, one municipality in our study area, Abbotsford, BC, produces twenty two percent of the Province of British Columbia's farm gate receipts (Ministry of Agriculture, personal communication). Abbotsford is at the heart of the region studied in this paper.

This study is part of a larger project to understand how farmland coexists with other land uses on the rural-urban fringe. Abbotsford and the surrounding Fraser Valley are typical of a landscape known as agriburbia, a form in which agriculture plays an active use. On the ruralurban fringe, agriburbia presents as an area where agricultural production is complexly intertwined with other uses (Newman, Powell, \& Wittman, 2015). Agriburban regions are unusual as they contain both a large residential population and a large diversity of small farms, creating a very fertile landscape for agricultural retail and tourism. The term "agriburbia” was coined by historian Paul Sandul (2010) to describe late-nineteenth century planned suburban developments which incorporated land for citrus production and other commercial horticulture activities and which were well connected to urban centres by transportation networks . Moving beyond Sandul's historical case study of planned integration of agriculture and residential development, agriburb can be applied more generally to areas which show a mixture of suburban development and economically-significant agriculture. Such mixing of residential and business development with farms is found throughout Canada and the United States, though it has been predominantly unplanned. Sprawling housing development often leapfrogged across the landscape, leaving sections of farmland between suburban areas (Conzen, 1960).

In this paper, we examine the Fraser Valley region to better understand the interface between agricultural production and the resident population. We are particularly interested in how non-farm residents interact with the rich agricultural landscape that surrounds them. We treat this interaction as a dialectic; as Ed Soja (1980) explores, there is a dialogue between 
culture and space occurring at the micro level that shapes cities. In the case of farmland on the rural-urban fringe, the continued existence of farmland in such regions depends heavily on the desires and opinions of surrounding non-farming residents. In this paper, we specifically study how the socio-spatial dialectic unfolds at on-farm retail outlets.

The continued existence of farmland on the fringe is important for several reasons, but in the case of the study region, the value of agricultural production is worth noting. The soils in the Fraser Valley are among the richest in Canada. The quality of the land combined with a climate of mild winters, rare freezes, and warm summers yields growing conditions that support a wide range of crops, including vegetables, berries, mushrooms, cereals, floriculture, and nursery stock. There is also diverse animal livestock production in the Fraser Valley, including poultry, dairy cattle, beef cattle, sheep, goats, horses, and pigs. British Columbia leads Canadian provinces in the production of blueberries, cranberries, and raspberries, and ranks second or third in several other commodities, including nursery products, mushrooms, dairy products, calves, and poultry; the Fraser Valley dominates the province's output of these agricultural products (BCMAL, 2012; FVRD, 2011). Accordingly, agriculture is a major driver of the economy in the Fraser Valley. The government of the Fraser Valley Regional District (which includes fringe areas but not metropolitan Vancouver) has identified agriculture as the foundation of the region's economy. Analyses of economic impact have determined that agriculture generates at least 11,300 full-time equivalent jobs and generates CAN \$1.8 billion in expenditures in Abbotsford alone; in Chilliwack, agriculture generates roughly 30 percent of the economic activity. Using conservative economic multipliers, agriculture's total value to the Fraser Valley is estimated at being over CAN \$2.5 billion (FVRD, 2011).

In agriburbia, agricultural production competes directly with residential development. In the Fraser Valley, as in other areas where high-quality farmland aligns with intense development pressure, agriburbia exists because of farmland preservation initiatives. In 1973, legislators in British Columbia passed the Agricultural Land Commission Act, which included both a directive to establish an Agricultural Land Reserve (ALR) of productive lands zoned as protected farmland, and established a provincial Agricultural Land Commission to oversee the ALR. Land protected by the ALR totalled roughly 5 percent of the province's land area, though the most productive of these lands are concentrated in three areas, one of which is the Lower Mainland, which includes metropolitan Vancouver and the larger Fraser Valley. A full description of the ALR can be found elsewhere (for example, (Stobbe, Eagle, \& Van Kooten, 2010) In the context of this study, the ALR is important as it stabilizes the rural-urban fringe, making the long-term investment needed to open a farm store practical.

The emergence of farm stores in this region follows from the exceptionally high costs of farming near urban development, the difficulty in acquiring additional land, and the availability of a ready market for high quality product. Despite their productivity and economic importance, there are ongoing questions about the financial viability of farming operations in the Fraser Valley (see, for example, ISFS \& BCFSN, 2016). Even with the presence of the Agricultural Land Reserve, there is still considerable purchase of land by non-farmers in speculation that it 
might someday be excluded from the reserve and opened to residential or industrial development (Stobbe, Cotteleer, \& Van Kooten, 2009, explore this aspect of the rural/urban fringe). Land prices are largely prohibitive for existing farmers looking to expand their operations, families in need of additional lands so new generations of farmers can join their operations, and new farmers. This has led some farmers to turn to diversify their on-farm operations, with farm stores being one such avenue of diversification.

"Farm stores" are permanent, on-farm retail outlets which, in addition to serving as yearround shopping destinations for items produced both on- and off-farm, may also be part of enterprises providing recreation and entertainment through agritourism activities. Using four case studies, we investigate the functions of farm stores in agriburbia. We were particularly interested in three distinct roles of farm stores; the role farm stores play in agritourism, whether farm stores help strengthen the demand for locally-produced food, and how farm stores help to shape and are shaped by the rural idyll, or the image that the public has of farm life.

\section{Farm stores and agritourism}

Agritourism is a focus of interest as an increasing number of operators on the rural-urban fringe are taking advantage of a large urban customer base and the growing interest in farm-related activities to increase farm gate sales through farm-related business activity. Extensive literature has emerged surrounding agritourism and its role in rural development. Useful overviews of agritourism exist about the study area (Ainley \& Smale, 2010; Stobbe et al., 2010; Tew \& Barbieri, 2012 ) and about direct marketing of farm products (Park, Mishra, \& Wozniak, 2014; Tippins, Rassuli, \& Hollander, 2002). Schilling et al. (2012) describe agritourism as a way for farmers to utilize all of the resources of their farms, and found that the large majority of agritourism activities occur on small farms such as those found in our study area as well.

This paper adds some attention to the understudied intersection of these areas, exploring those operations that blend direct sales with agritourism. The question of the role of on-farm retail operations in the agriburban landscape is particularly important in British Columbia, where the use of farm land is highly regulated. As part of maintaining British Columbia's Agricultural Land Reserve, there are strict rules for the construction of farm buildings and business activities that can take place on protected farmland. The intention of these regulations is to prevent excessive intrusion of non-agricultural uses onto the province's limited amount of land that is suitable for farming. Through our study of the role that farm stores play in the agriburban landscape, we argue that they play a key role in local food systems, as well as contribute to the goals of sustaining agricultural activity and the agricultural land base in the region.

We drew on several definitions of agritourism in this work. Arroyo, Barbieri, and Rich (2013) define agritourism as "farming-related activities carried out on a working farm or other agricultural settings for entertainment or education purposes” (p. 45). Che, Veeck, and Veeck (2005) define it more specifically as "any agricultural operation that caters directly to the general public with retail sales and/or the provision of services, involving food, fiber, flowers, trees, 
shrubs, and other farm products and conducting sales at the production location” (p. 227). In the study region, the nature of direct sales on farm falls under guidelines and restrictions for what kinds of businesses can operate and what kinds of structures can be built on ALR lands. The Agricultural Land Commission provides policies protecting on-farm “farm retail sales," which it defines as activities where all of the farm products offered for sale are produced on the farm where the sales are taking place. Specifically, "the total area, both indoors and outdoors, used for the retail sales of all products [should] not exceed $300 \mathrm{~m}^{2}$ ”. In addition, "if at least 50 percent of that retail sales area is limited to the sale of farm products produced (A) on the farm on which the retail sales are taking place, or (B) by an association as defined in the Cooperative Association Act to which the owner of the farm on which the retail sales are taking place belongs” (Commission, 2016). The ALC also provides policies guiding agritourism activities on ALR lands, allowing "agri-tourism activities, other than accommodation, on land that is classified as a farm under the Assessment Act, if the use is temporary and seasonal, and promotes or markets farm products grown, raised or processed on the farm” (Commission, 2003). Agritourism activities involving accommodations are regulated by other policies, and permanent agritourism activities require approval by the ALC (Commission, 2003).

While these are policies set at the provincial level, much of the actual regulation of farm land use occurs at the local government level, and there are provisions for local governments to enact bylaws to further regulate farm retail and agritourism activities. These bylaws require approval by the Ministry of Agriculture. Despite the policies set out by the ALC, retail and agritourism activities on ALR lands can be contentious issues. The significance of the issues is indicated by the September 2015 production and distribution of a discussion paper entitled, "Regulating Agri-tourism and Farm Retail Sales in the Agricultural Land Reserve.” This document includes draft bylaw standards that the Minister of Agriculture sought feedback on for several months before implementing as official bylaw standards to guide the municipal development of zoning and farm bylaws; the official bylaw standards had not been released at the time of submission of this article. This document indicates that local governments in British Columbia had been seeking greater clarity regarding agritourism and farm retail sales (BCMA, 2015). Questions over the appropriateness of farm stores on ALR land underscore the need for their study. We included questions regarding regulations in our interview protocol.

Farm stores across the Lower Fraser Valley, and particularly our four case studies, are regularly listed in directories of agritourism opportunities directed largely at urban residents. As noted in (Feagan, Morris, \& Krug, 2004) the customer base for agricultural marketing near large centres is dominated by customers who prize experience as much as food, though we will discuss how this can take many forms in practice. Indeed, in scholarly literature, farm stores are often considered as a component $\theta$ for subcategory of agritourism enterprises (Che et al., 2005; Talbot, 2012). Barbieri (2010) makes some distinction by noting that agritourism can have synergies with other on-farm enterprises, as farm visitors are likely customers for on-farm stores and restaurants. As we demonstrate in this paper, these farm stores need to be considered beyond the context of agritourism as their primary functions extend beyond drawing recreation- and 
entertainment-driven tourists to farms; however, they also need specific consideration outside of the larger umbrella of direct marketing, since they provide experiences beyond only the opportunity to purchase farm goods, including service of prepared foods. This multifunctionality is in part driven in our case study area by a robust local food movement.

\section{Farm stores and the local food movement}

Local food is a large part of Canada's culinary identity (Newman, 2017), and the West Coast is a particularly active hub of interest in using local products. The term "locavore" was coined in Northern California by a group of women who committed to eating locally after reading Gary Nabhan's (2009) book Coming Home to Eat ${ }^{1}$. However, it was a couple from Vancouver, Alisa Smith and Jamie MacKinnon, who popularized the term with their book The 100 Mile Diet (2009). Local food has become a watchword of Vancouver cuisine. Regional place-based food initiatives have been positioned as a sustainable alternative to long global agricultural chains, and the rural-urban fringe is often the site suggested for such initiatives. A rich body of research supports the development of place-based food initiatives, such as Marsden's (2013) work on the role of regional food systems in sustainable development in both the country and the city, and Friedmann's (2007) work on connecting public institutions and other large food purchasers with local producers. Discussion of the potential impact of regional place-based food systems has never been more robust.

At farm stores, the public interacts directly with the agricultural lands that surround their communities, engaging in a dialectic with the source of their food. Soja describes spatial dialectics as two-way, and we did want to confirm that this is true; what the customer purchases is certainly shaped by what is grown, but does the customer base influence what is produced? We were particularly interested in the nature of the customers using farm stores. We were also interested in how well these stores perform for the farmers who run them, and for the farmers who market product through them. On the surface, providing agritourism venues and provisioning the local market are two very different activities, and we were interested in how operators balance these two different markets. While farms in agriburbia produce food sold both locally and exported they may also serve many other functions.

Multifunctionality is well-described in a synthesis written by Zasada (2011), multifunctionality involves "integration of land uses and functions beyond traditional food production”, and was developed "as a framework for rural development to enable agriculture to cope with post-productive challenges” (p. 641). Zasada notes that "Multifunctional agriculture encompasses various strategies and activity fields for farms, such as diversification on and off the farm, specialisation in production and processing, direct marketing or measures in nature and landscape management” (p. 641). In particular, Zasada (2011) notes that the interplay with the

\footnotetext{
${ }^{1}$ Originally published in 2001.
} 
urban area of multifunctional peri-urban agriculture is not fully understood, and needs further research. However the demands, values, and perceptions of urban residents play a significant role in the multifunctionality of agriburban farms (Ives \& Kendal, 2013).

\section{Farm stores and the countryside idyll}

The authentic scarcity provided by seasonality is part of the consumer's expectation of what a visit to farm country should entail. The vision of the farm in the collective imagination, including elements of traditional or stereotypical rural imagery, are part of what has been referred to as "the countryside ideal" and elsewhere has been deemed "the rural idyll" (Bell, 2006; Bunce \& Bunce, 1994). The above forces of demand for local food and agritourism shape what urban customers expect when visiting a farm store, but there are larger social constructs of what a farm looks like. We were curious as to what extent operators shape their stores to meet what they think customers expect, a set of culturally-entrenched expectations of how farms should appear. Zasada (2011) has noted that, "Although there is generally a high appreciation of farmland in the countryside around towns, the visual aspects of the agricultural countryside are prioritised" (p. 642).

Bunce and Bunce (1994) present the countryside ideal as a product of popular culture and our minds, while also arguing that it has grown beyond literature and philosophy "into the realms of popular and tangible expression in the actual landscapes and living spaces of modern society” (p. 2). This is embodied when on-farm businesses display (whether or not they are actually in use) such items as rusty scythes, antique tractors, hay bales, wooden barrels, red barns (in images or as structures), rail fences, gingham curtains and other symbols of what rural, and in particular rural agricultural, life is imagined to be like. As Hinrichs (1996) has observed, the rural idyll has implications for farmers: "Whereas the social role of rural producers once rested largely on their actual production of food, fuel or fiber, their present social role also encompasses the presentation of idealized images of rural life, valued by groups originating from or based elsewhere” (p. 260).

Rurality, and the symbols surrounding it, have become commodities to be consumed. At the most basic level, this relationship influences crop choice; as Powell and Engelhardt (2015) note in the case of the pumpkin, its role as an element of popular culture and its position as a food crop is complicated. Unlike many crops grown on small farms, pumpkin sales spike sharply for the fall holiday season. Based on our preliminary observations of farm stores, we hypothesized that use of visual elements of the countryside ideal, including traditional or stereotypical farm and rural imagery, in their farms and farm buildings would be a consistent part of their business environments. In our study, we both observed elements of the rural idyll through photographic documentation and included questions to probe the intentionality of farm imagery. 


\section{Applied research methods}

In this study, our team used a multiple case study method, following the collective case study model identified by Stake (2005) in which a group of cases is studied to allow for comparison. Even with multiple sites, a case study methodology is limited in that one can't draw general conclusions from a handful of cases, but case study methodology is an appropriate tool when a holistic, in-depth investigation of a specific space is needed (Feagin, Orum, \& Sjoberg, 1991) The four case studies have been chosen to provide a diversity of expected information content. We gathered information on all such farm enterprises in the region (shown in figure 1), and then analysed blogs and chose the four most popular sites for close analysis. These include two sites that have farm retail as a primary focus, one with agritourism as a primary focus, and one with a balance of the two.

Through interviews, visits, and photographic documentation we followed a broadly phenomenological method described as topography or place-writing that has been used by Coles (2013) in a study of Bourough Market in London; capturing spaces that are at heart full of sights, sounds, smells and tastes is always incomplete at best, but certainly is supported by repeated visits and the use of photography. We also informally interviewed local decision makers to follow up on identified conflicts between operators and various levels of government; as several active land-use decisions were in progress on-record interviews were declined, but several informal conversations provided insight.

While our work on agriculture and peri-urban development in the Fraser Valley region meant that we had familiarity with the farm store landscape, in the course of our case study work, we identified the need for a database and map of the types of farm retail outlets that our case studies represented. We established a database of farm stores in the Lower Fraser Valley, beginning with what we knew from our experience in the region, and completed using internet searches, lists on BC and municipal websites, and verification of the existence and characteristics of listed stores through phone calls and visits. We chose the Lower Fraser Valley (areas south of the Fraser River, along with Richmond, which is at its mouth), as this area corresponded to detailed mapping of changes in the Agricultural Land Reserve over time that other members of our research centre had been working on. After finalizing the database in Microsoft Access, we used Arc GIS to map the location and characteristics of these farm stores on a base map of the Agricultural Land Reserve. Our database of farm stores only includes permanent on-farm retail outlets. We did not include seasonal farm stands, or farm markets which are not situated on farms, though the roles of these in the agriburban landscape could also be fruitful areas of study. 


\section{Results}

The construction of a farm store database yielded a list of 49 farm stores in our study area of municipalities south of the Fraser River and Richmond. Of these farm stores, 47 are located on farms within the ALR, and 2 are located on farms outside of the reserve. ${ }^{2}$ These stores are shown in Figure 1.

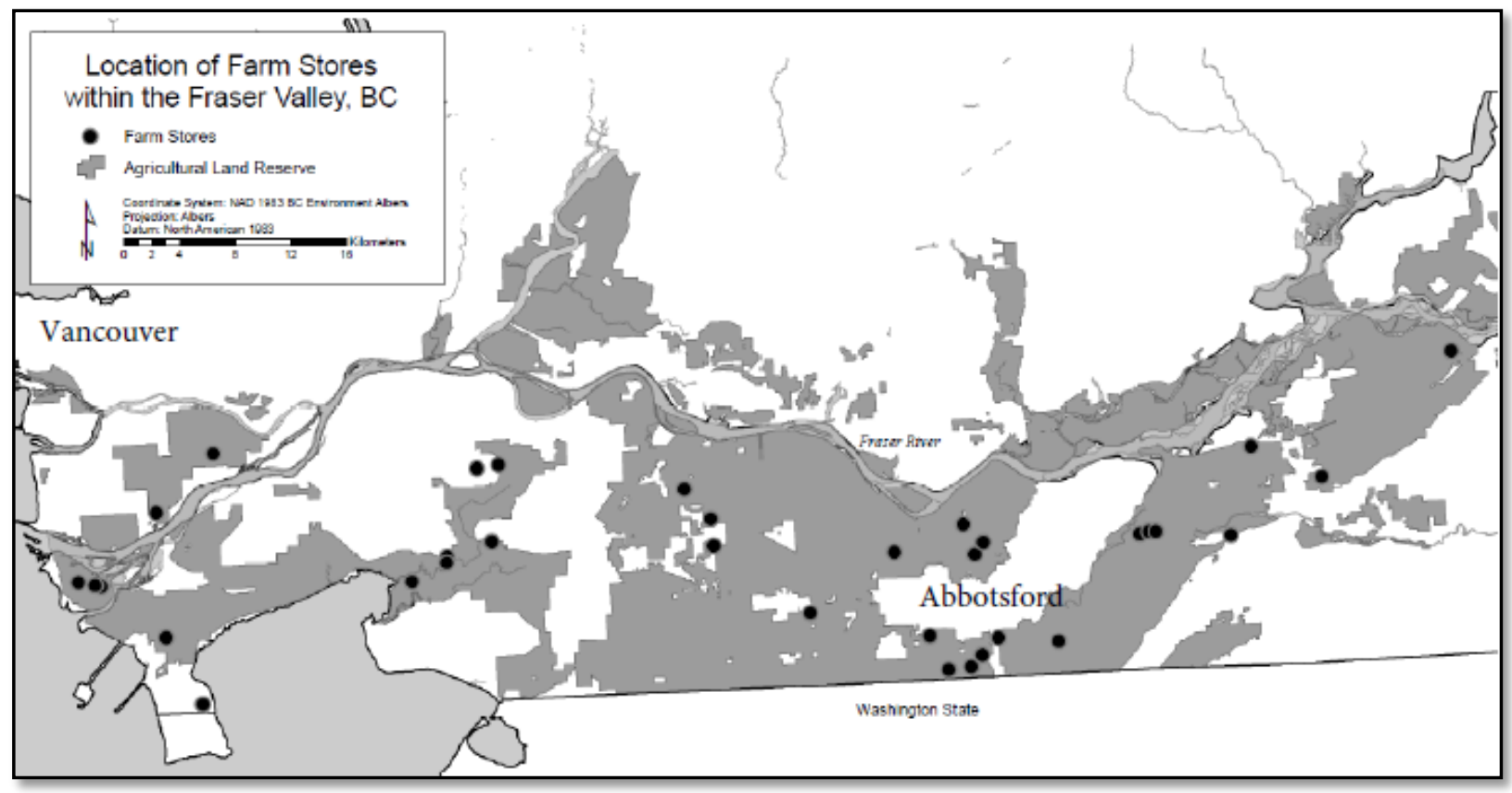

Figure 1: Farm stores south of the Fraser River and in Richmond, in the Lower Fraser Valley of British Columbia. Cartography credit: Kathryn Kelly-Freiberg.

From this larger sample we chose four sites for close analysis as explained above. All four of our case study sites are located in the ALR; we chose to exclude the two sites outside of the ALR as possible case studies in part because they are so unusual and in part because they operate under a different set of regulation. Within this still large subset we chose sites that were year round or very close to year round, and explicitly brand themselves as agritourism sites. We then chose four of roughly the same size within an order of magnitude. Their locations are within agriburbia at two scales. First, they are part of the agriburban region surrounding Vancouver. Second, they are each located in peri-urban areas surrounding the urban centres of the municipalities in which they are located. All of the locations advertise to consumers in both Vancouver and municipalities throughout the Fraser Valley. The locations are shown in Figure 2.

\footnotetext{
${ }^{2}$ While farm operations outside of the ALR are rare in the Fraser Valley, a few isolated ones do exist in several municipalities.
} 


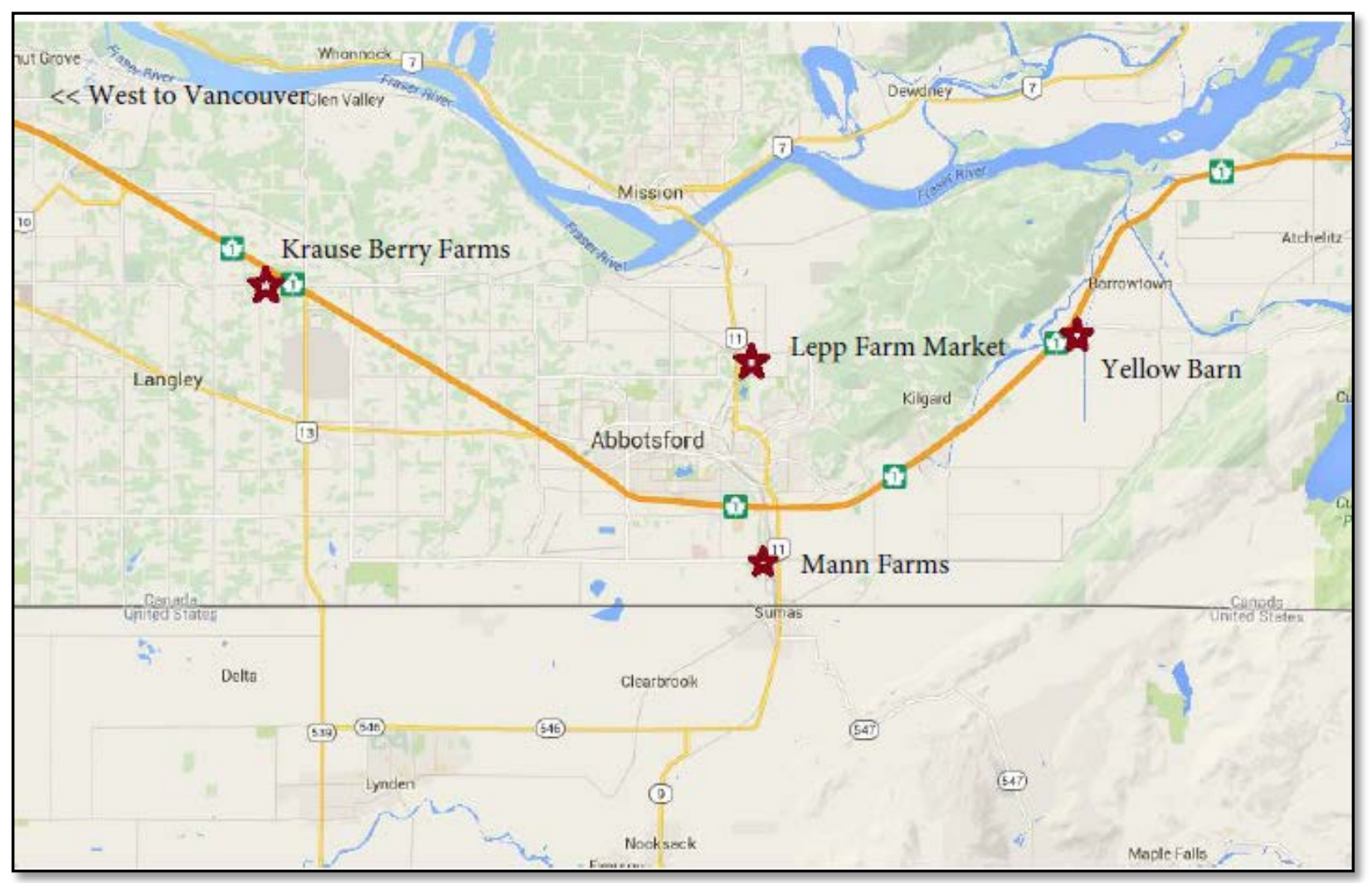

Figure 2: Four farm store sites near Abbotsford selected for study (Map by Lisa Powell, created using Google Maps)

\section{Site descriptions and photo analysis}

Through multiple site visits and through coding the interviews for "history", the research team assembled descriptions of each site. We photographed items typical of the rural idyll, and followed up with discussion in the interviews.

Maan Farms Country Experience: Maan Farms is located near the urbanized area of Abbotsford, British Columbia, a few minutes off of the Trans-Canada highway. Jawahar and Gurbachan Maan and their three children started Maan Farms in 1977. In 1982, they opened their first farm stand on McKenzie Road in Abbotsford. They initially sold field vegetable crops and some strawberries; when community members expressed interest in buying fruits locally, they expanded their range of berries and other crops. They opened a second roadside stand in 1995 on Townline Road, and opened their current location, also on McKenzie Road, in 2006. In 2006, Maan Farms added a corn maze, pumpkin patch, and Upick berries to their farm stand; in 2007, they added a play area and petting zoo, and began to offer school tours. In 2012, Maan Farms added a barn facility, which included a country kitchen (food service), country market, and banquet hall, and in 2013, they opened an Estate Winery. The barn facility burned in the summer of 2014, and has now reopened. 
According to Amir Maan, grandson of the founders, 80 percent of the products sold at Maan Farms are grown locally, including the fruits and vegetables grown on their land, which comprise approximately 95 percent of the total locally-produced items they sell. Amir noted that he has seen increased consumer demand for local food and for agritourism activities, which he said "go hand in hand" in people "knowing where their food comes from." To help satisfy local demand through its own products and brand, Maan farms is developing its own packaging so that it will be "just as easy and efficient to purchase here as it is at Safeway" ${ }^{3}$-Amir acknowledged that from a business standpoint it would be better to be located closer to Vancouver, where some of their customers come from; however, it would not be as practical to sell the fresh products from their farm land, which is in several locations around the municipality of Abbotsford. In addition to retail and agritourism, Amir emphasized the educational component of Maan Farms, which includes offering formal school tours and providing an opportunity for visitor-customers "actually coming out to the farm, learning, being educated and really getting a sense of what it takes to grow their food and how it actually ends up on the dinner table. So it just has been more of actually putting thought into what they are actually eating.”

Maan Farms includes several items of what could be thought of as rural idyll, including red barn structures, a petting zoo, antique tractors, hay bales, and their signature "Gotel 6" goat motel. Amir frames these elements as educational, as providing access for urban families to encounter farm animals. The farm and stand is within the ALR, and their high ratio of on-farm product falls within the ALC guidelines for land use. They did not report any problems with other elements such as the kitchen and haunted corn maze.

The Yellow Barn: The Yellow Barn is in the municipality of Abbotsford, but sits nearly exactly between the urban sections of Abbotsford and Chilliwack. It is located at an exit from the Trans-Canada Highway, and this exit also serves as the primary route to two popular outdoor recreation areas. It is very visible from the highway in both directions. Since 1973, Alex and Marjorie Hodgins-Smith have grown sweet corn, selling it in relatively small quantities from their yard. Prior to the opening of the farm gate shop, they grew 60 acres of corn, all of which was sold wholesale to vendors traveling to Vancouver to sell it out of their trucks. Their farming operation struggled during the recession of the early 1980s, and, knowing they had the potential to diversify by growing other vegetables, in 1986 they purchased the property on No. 3 Road where the Yellow Barn is now located. They opened for business in 1987 as Hodgins-Smith Family Produce. The building has always been yellow and green, the primary colours of corn. Customers and the public alike would refer to the building not by its name, but by its pseudonym, The Yellow Barn, which eventually became the official name of the business.

When Hodgins-Smith Family Produce initially opened, they grew seventeen varieties of sweet corn; to meet demand, they now grow multiple varieties of vegetables, including ethnoculturally Asian ones. The Yellow Barn sells both corn and other vegetables from the fields surrounding the store, as well as from offsite fields and other local producers; in the summer

\footnotetext{
${ }^{3}$ A multinational grocery chain.
} 
months they also sell produce from BC's Okanagan region. In addition to produce sales, the Yellow Barn also sells preserves, canned goods, and baked goods produced on site, as well as some general grocery and snack food items. They have a deli counter that focuses on locallysourced meats and cheeses, and a small restaurant. They also sell some antiques and other used items in their entry foyer, as well as some convenience household and toiletry items that may be of use to nearby residents and those traveling to the outdoor recreation areas.

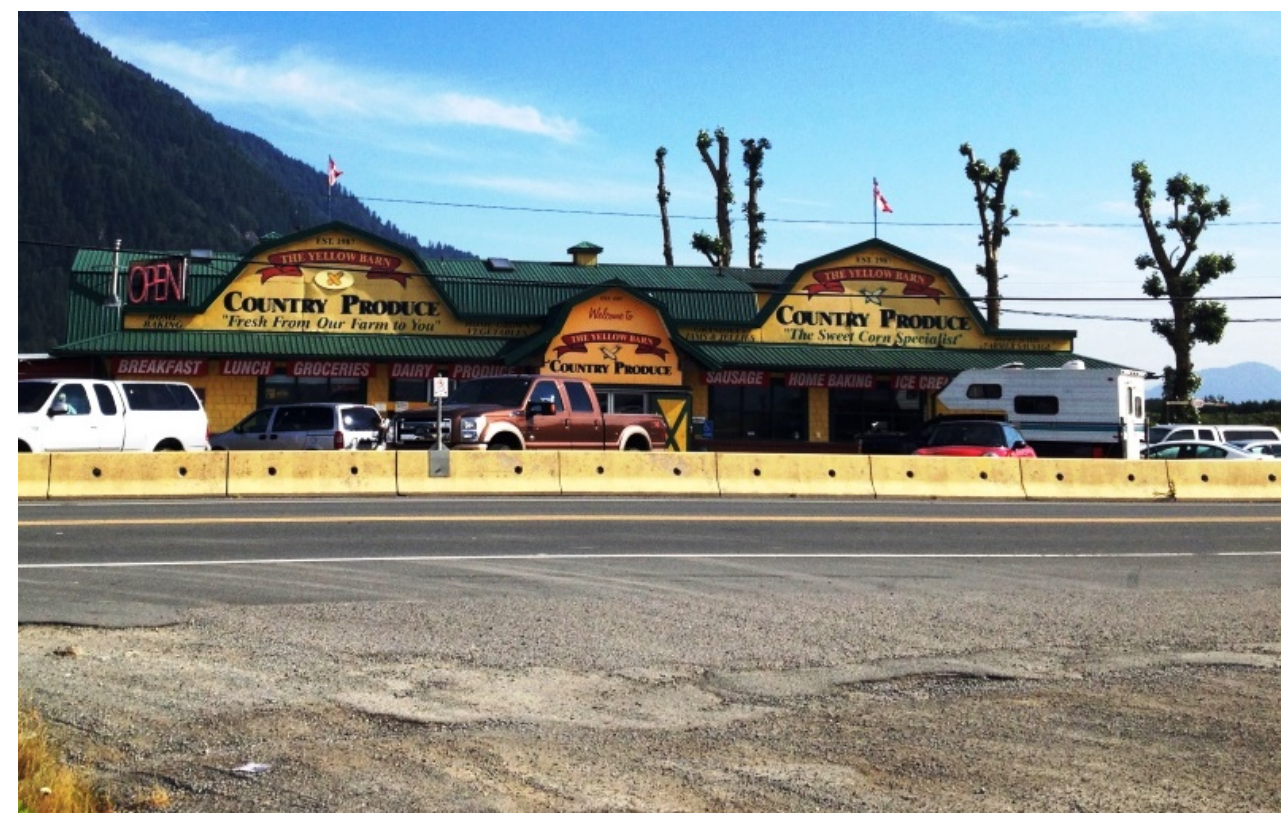

Figure 3: The Yellow Barn (Photo by Lenore Newman)

While the Yellow Barn does not currently have any additional agritourism activities, for a ten year period from the early 1990s through the early 2000s, the Hodgins-Smiths held hour-long "pumpkin tours," which involved educational components. Marjorie described them as "a good way to bring the city to us." The pumpkin tours proved to be too much work for the return. The Hodgins-Smiths still encourage their staff to offer educational information to customers by answering questions about food sources and preparation. The farm store, in particular its restaurant, has become a popular local meeting place for people from the surrounding communities of Abbotsford and Chilliwack, who say, "Oh we'll just meet at the Yellow Barn.” It is also located directly on popular commuter routes, and serves as a market to both locals and those passing through on their way to the recreation sites. The Yellow Barn meets the rural idyll primarily through its structure which, as one might expect, is a large yellow barn. The store sits within the ALR, but no issues around operating were reported at the time of the interview. The café within the barn continues to grow in popularity.

Krause Berry Farms \& Estate Winery: Krause Berry Farms \& Estate Winery is located on $248^{\text {th }}$ Street in Langley, BC, a municipality which is part of the Metro Vancouver Regional District. It is the closest to Vancouver of the four case study sites; while the location is near the 
Trans-Canada Highway, several kilometres of driving on rural roads are required to reach Krause from the highway. Alf Krause, along with his wife Sandee, have been farming parts of the location for over 40 years. Alf started the operation by planting one acre of strawberries in 1974 . When the processing industry became stale, the Krause family identified that in order to make more money it needed to engage in direct marketing, production of value-added products, and diversification. Krause Berry Farms began operating as an agritourism venture in 2000; their property is now over 200 acres, which hold both berry (strawberries, blueberries, blackberries) and vegetable fields, in addition to the all the facilities for their agritourism operation.

According to Krause, when they diversified their business beyond growing berries for the processing market, they did so with the Vancouver market in mind. The Krause family found that people were willing to drive up to an hour to visit the farm, and they were 15 minutes closer to Vancouver than competing operations in Abbotsford. In addition to fresh produce, Krause's retail store sells products made from their farm output, including preserves, syrups, pies, and other baked goods. Their store also sells canning supplies, along with gifts and décor items. The restaurant strives to offer innovative foods, such as corn pizza. For its agritourism offerings, Krause offers seasonal u-pick berries, and during the summer season, offers "country tractor train rides," a baby farm animal area, and large picket fenced Future Farmers at-Play playground. With the goal of mutual promotion and benefit, Krause has partnered with other food and farm businesses on $248^{\text {th }}$ Street, including a turkey farm, honey farm, alpaca farm, and a butcher shop, to create the Otter 248 Street Historic Trail.

Krause Farm is by far the operation that plays most heavily to the rural idyll. Iconography includes covered wagons, a cowboy-themed wine room, a general store featuring traditional country crafts, and many other elements of country kitsch. Of the operations, Krause is much less a farm store and more of a destination, though people do come to purchase berries or take part in the u-pick. Their berry pies and corn pizza are well known in the region, and can be purchased and taken home.

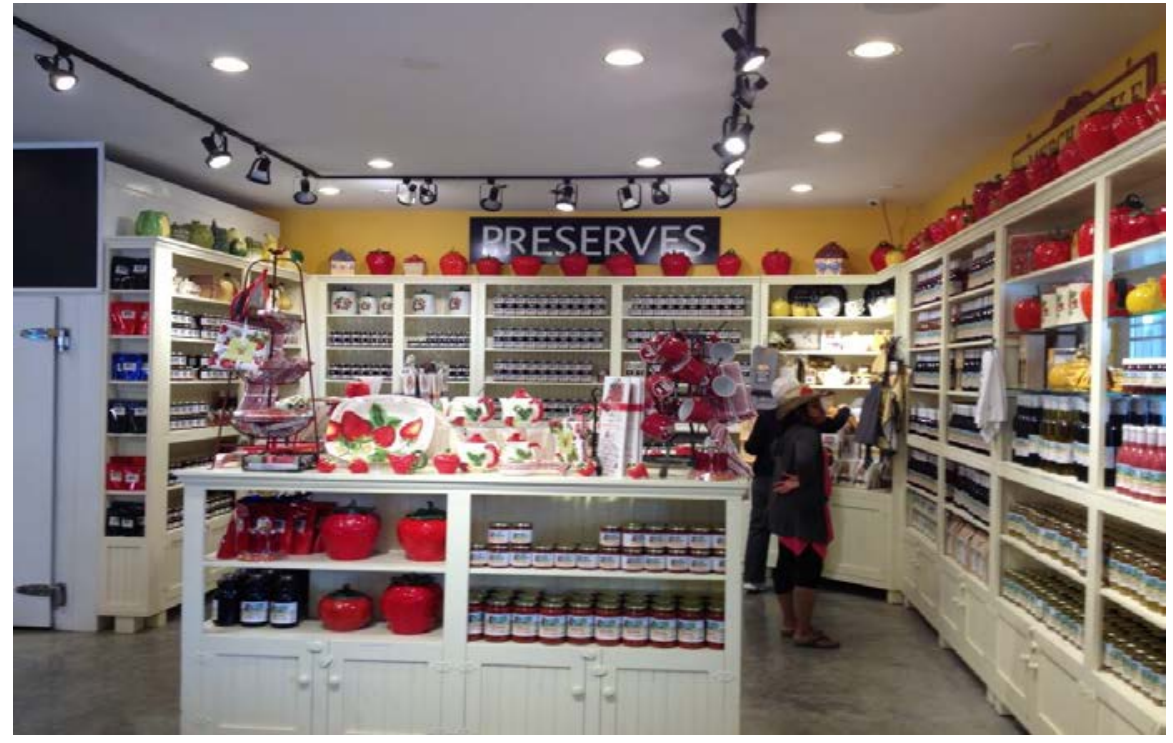

Figure 4: Retail store at Krause Berry Farms (Photo by Lenore Newman) 
Lepp Farm Market: The Lepp Farm Market sits on Highway 11, on the periphery of Abbotsford. Robb and Charlotte Lepp have operated the farm adjacent to the store for several decades, raising pork, chicken, corn, and other vegetables. The Lepp family had been selling corn from a shack near the market's current location since 1995; they initially sold their farm products to other retailers in Abbotsford and elsewhere. The Lepp family identified the need for a store where they could sell their own products. In 2009, they opened the market in its current form, with the goals of both selling their own farm output locally, and offering gourmet food products and ingredients that were not easy to source in the Fraser Valley outside of the City of Vancouver. Stephanie Wiebe, Lepp's Produce Manager, who has worked there five years, noted that during the summer time, over half of the produce sold comes from the Lepp farm land. The Lepp family also continue to raise pork and chicken on the farm where the store is located, and sell it in the store. The Lepp family also has an orchard in the Okanagan, where they raise apples, peaches, apricots and cherries.

In addition to retail sales of produce, meat, cheese, bread, and grocery items, Lepp Market also has a deli counter and an in-store café. The deli serves meats primarily raised in BC and processed on site. The café also focuses on meats raised by the Lepp family, and employs a Red Seal chef [a Canadian professional certification]. According to Wiebe, the location on a main road into the urbanized part of Abbotsford helps to make Lepp a convenient place to shop for individuals driving to and from work, as well as people who live nearby. Lepp Market also attracts customers from both the Abbotsford area and the more distant urban centre of Vancouver through its seasonal corn and peach festival, BBQ competition, Christmas market, and cooking classes.

Of the case studies, Lepp Farm employs the least rural imagery, though the structure is vaguely barn-like and displays sometimes feature hay bales. Of the operations, Lepp has had the most conflict with their local government; local retailers have complained that Lepp receives unfair advantage by operating on the ALR. Of the stores Lepp Farms is the closest to downtown Abbotsford, and most closely resembles a retail store in range of products and in strength of offerings across seasons. Though they are constrained by ALR rules in what they offer, they pay much lower taxes as their store is located "on farm". They are currently considering removing the store site from the ALR to resolve this tension.

\section{Agritourism, local food and the rural idyll}

From the interview transcripts we also coded for local food and agritourism, in an attempt to understand how each operator balances these two sides to rural retail in this region. In the case of Mann farms, they maintain a strong focus on local foods despite a significant secondary focus on agritourism. As Amir Mann noted, "That's where we pride ourselves is on it has a Mann Farms label you know it's locally grown by us." He sees the agritourism as complementary and as a tool for drawing customers from farther away. He says of Vancouverites, "they want to have a farm experience. So when people do come out to our farm they stay there for more than a couple 
hours. Sometimes [they] stay here for half a day: they kind of go through the petting zoo, they go through the corn maze, [they take] a hay wagon ride.”

Amir has focused on providing a unique experience that doesn't compete with surrounding stores, but rather complements potential farm circle tours (brochures are available in Abbotsford for customers wanting to visit a variety of agricultural outlets in a day). He explains "We always try to separate ourselves. That's helped tremendously [in terms of establishing a brand]. And not having to compete because when you provide some sort of different niche or product such as agritourism.”

The Yellow Barn has expanded from primarily offering corn to offering a much wider array of products. They stressed the importance of their location (at an important freeway junction). They describe their growth as organic: "but people did come for our corn and from there we just developed and expanded.” Even the name of the operation emerged from the customers as noted above. "People come here to meet other people from other places, and would agree to meet at 'The Yellow Barn' and so I decided we would just call it the Yellow Barn.” The Yellow Barn diversified further with a small restaurant area, which they saw as critical to extending business hours. They note, “And, no with the little restaurant, well, I’ve felt I've needed to do that. In the mornings it can be as dead as a doornail here, or it had been in the past.

Now it is not. You come by here at 9:00 - 9:30 in the morning and the parking lot is full because they're in here (the restaurant side). But then come noon, we have lots of restaurant people at noon as well. But then, maybe I should say 1:00 or so the business shifts and it's all over there (on the produce market side).” Marjorie also noted the importance of local foods, and suggested a shift in housing style for increased popularity. In short, people without gardens need access to local foods. She observes, “You know, so they can’t grow anything. So the next best thing is to come to a place like ours. So that's one of the changes. People don't live on any property. A lot of them don't live on property where they can grow things.”

Marjorie also commented on agritourism being, in their case, too much work. "A few years ago we did pumpkin tours and that I felt was a good way to bring the city to us. I just go too tired. I did it for 10 years and every October by the end of October I was a basket case. We did up to 6 tours a day. They were basically an hour and you had a half hour in between to get ready for the next tour to come and it rained a lot in October.”

The Krause family diversified to make their farm economically viable given a shrinking processing industry and rising land costs. Krause notes, "We were looking how to economically make more money. The process industry was very stale, just staying the same. So the only way you could make more was by either, economies of scale, getting larger and larger, and finding ways to reduce expenses, because the income was always dictated. So it was looking for ways to control our own destiny."

They see their proximity to the city of Vancouver as an advantage: "Location is always a very important part of agritourism. If you don't have a location then you have to develop a reason or a means of getting people to come out to your location. And because our location was beneficial to a degree because we're closer to Vancouver.” They also note the importance of 
berries, despite their strong focus on agritourism: "the initial draw was fresh berries. And then from there, seeing what people can do with fresh berries, because you can only buy so many. But then ... you can already have a finished dessert like the pie, or corn pizza is a product that we came up with because we can only sell so many corn cobs, but we can sell more corn on another venue as well, another added value product. So it's finding ways to use the product in number of ways but it all starts with the fresh berries as the focus.”

Lepp Farm Market followed a similar evolution with a very different outcome. The Lepp family attempted to fill a niche, a representative comments that "I mean they always had the corn shack on the corner, but they wanted a place where they could sell their own products. "All they were doing was shipping everything else elsewhere and there was no place in Abbotsford that was doing anything like this." Lepp then branched out through seasonal events: "We've done in the past a big BBQ competition, we have our Christmas at the farmer table event coming up, so a big Christmas market that we do outside.” Lepp intentionally caters to a different shopper than some of the other markets: "We do cater to people who are more of a high end client, but that's because of what we offer. Everything that we bring in is really good quality I think that people, now, compared to years ago care about where their food is coming from more and they want to know where it's coming from more. So, I mean we're a part of circle tours.”

The aesthetic of each stand was surprisingly unconscious. The Yellow Barn is painted in tallow and green, the colours of corn. At Lepp, questions about the hay bales did not reveal any really targeted marketing; farm stores use hay bales. At Mann's the Mann family have more directly embraced the rural idyll with tractors, and petting zoo structures in barn shapes. And at Krause, the family sees the old west motif and the country store as part of the experience their customers are coming for, right down to the "porch" café where one can eat corn pizza and berry pie.

\section{Discussion and conclusions}

While each of the case study sites is unique, they contribute to a broader understanding of how farm stores function in the agriburbia. Each of the four case study sites began as a farming operation focused on producing a limited number of food crops and adopted multifunctional agriculture as part of strategies for economic sustainability and/or expansion. Of our four case studies, three significantly incorporated agritourism activities beyond retail sales of farm products and on-site dining, and the fourth had offered agritourism activities in the past. All of the case study sites focused their businesses around the provision of high quality, locallyproduced and value-added foods made from locally-grown ingredients, and interviewees indicated that they value their role in connecting consumers to the source of their food.

All of the case studies are successful businesses, suggesting that farm store sales and agritourism are likely to be positive adaptations to the challenges of farming near a major urban centre. As noted by the Krause family the option to expand the farm's land base wasn't available 
(small farm sizes are common near cities) and so value-added and intensive production are required. The owners of the Yellow Barn and their move away from pumpkin tours highlight one of the downsides of agritourism: it is labour intensive. Farmers offering both agritourism and farm gate sales must balance workload with reward. There was also a general sense among the interviewees that one could diversify too much and thus diminish a key niche or brand. In studying agritourism, the provision of local food, and the catering to a rural idyll, we found a delicate balance. Operators could draw on all three, but each operator in this study picked one main aspect to highlight. Likely developing a brand requires this approach. This is an interesting avenue for further study.

Though we can't draw general conclusions from case studies in one area, it is likely that in regions on rural-urban fringes where there is both an interest in local food and a varied farm landscape on small farms, farm stores will appear. Their popularity, which is increasing according to the interview subjects, hints at the wider interest in local foods eaten in season.

Our study found that not only urbanites are drawn to such operations, but that local customers were also very important to these businesses. While the case study site most closely located to Vancouver, Krause framed its customer base as primarily from that city, the other three operations indicated that the local populations and residents from surrounding municipalities were significant parts of their customer base. Accordingly, these farm stores serve key roles in enabling local consumers to purchase locally-produced foods; in the case of Maan Farms and Lepp Farm, local items are offered by the local businesses at a similar level of convenience to what they would be in a large chain supermarket. In addition to food system localization, the farm stores can serve other important functions in the day-to-day lives of members of the communities in which they are located, and our case studies echo Barbieri's (2010) findings about the positive extra-economic effects of such on-farm entrepreneurial efforts. For example, the Yellow Barn contributes to strengthening community ties by providing a meeting place, and all of the sites foster community food and agriculture education to some degree. Lepp donates time, money, and product to various causes in the Abbotsford community.

While we acknowledge the limitations of generalizing from case studies, the broader literature on farm diversification discussed above and the demands of the regional land economy suggest that it is likely that farm stores throughout the agriburban region surrounding Vancouver serve similar functions. Farm stores help to maintain the economic viability of family farms, to localize food systems, and to provide educational opportunities for consumers. By helping to maintain the financial viability of farm operations on ALR lands in agriburbia, farm stores help to protect these lands as they reduce the likelihood of their being sold to buyers speculating on the possibility of their being removed from the reserve. By educating consumers about food and agriculture, farm stores help to build local support for agriculture and for preservation and protection measures such as the ALR. While close attention to the use of ALR lands for purposes other than farming itself is essential, this study indicates that farm stores have the potential to play a vital role in sustaining agriculture in the Lower Fraser Valley, a role which may be replicated elsewhere. 
As a final finding, the operators reported only somewhat consciously designing their stands and attractions to meet the rural idyll. To a large degree they designed them to mirror their own assumptions of what a farm selling to the broader public should look like, in effect showing the rural idyll is internalized among farmers as well, even though they know this image does not reflect the true nature of the modern farm. More study into this effect is needed.

Acknowledgements: We would like to acknowledge the support of the Social Sciences and Humanities Research Council of Canada, and the research office of the University of the Fraser Valley. The primary and secondary author would like to thank the student authors, who put so much work into this project. We would also like to thank our reviewers for their excellent comments.

\section{References}

Ainley, S., \& Smale, B. (2010). A profile of Canadian agritourists and the benefits they seek. Journal of Rural and Community Development, 5(1), 58-75.

Arroyo, C. G., Barbieri, C., \& Rich, S. R. (2013). Defining agritourism: A comparative study of stakeholders' perceptions in Missouri and North Carolina. Tourism Management, 37, 39-47.

Barbieri, C. (2010). An importance-performance analysis of the motivations behind agritourism and other farm enterprise developments in Canada. Journal of Rural and Community Development, 5(1), 1-20.

BCMA. (2015). Regulating Agri-Tourism and Farm Retail Sales in the Agricultural Land Reserve: Discussion Paper and Proposed Minister’s Bylaw Standards.

BCMAL. (2012). 2011 Census of Agriculture: British Columbia Highlights. .

Bell, D. (2006). Variations on the rural idyll. In T. Marsden, P. H. Mooney, P. J. Cloke (Eds.), Handbook of rural studies (pp. 149-160). London: Sage.

Bunce, M. F., \& Bunce, M. (1994). The countryside ideal: Anglo-American images of landscape: Psychology Press.

Che, D., Veeck, A., \& Veeck, G. (2005). Sustaining production and strengthening the agritourism product: Linkages among Michigan agritourism destinations. Agriculture and Human Values, 22(2), 225-234.

Coles, B. F. (2013). Making the market place: A topography of Borough Market, London. Cultural Geographies, 1474474013479845. 
Commission, A. L. (2003). Activities Designated as Farm Use: Agri-Tourism Activities in the ALR.

Commission, A. L. (2016). Activities Designated as Farm Use: Farm Retail Sales in the ALR.

Conzen, M. R. G. (1960). Alnwick, Northumberland: A study in town-plan analysis. Transactions and Papers (Institute of British Geographers)(27), iii-122.

Feagan, R., Morris, D., \& Krug, K. (2004). Niagara region farmers' markets: local food systems and sustainability considerations. Local Environment, 9(3), 235-254.

Feagin, J. R., Orum, A. M., \& Sjoberg, G. (1991). A case for the case study: UNC Press Books.

Friedmann, H. (2007). Scaling up: Bringing public institutions and food service corporations into the project for a local, sustainable food system in Ontario. Agriculture and Human Values, 24(3), 389-398.

FVRD. (2011). Regional Snapshot Series: Agriculture--Agricultural Economy in the Fraser Valley Regional District.

Hinrichs, C. C. (1996). Consuming images: making and marketing Vermont as distinctive rural place. Creating the Countryside. Temple University Press, Philadelphia, 259-278.

ISFS, K., \& BCFSN. (2016). Home on the Range: Cost Pressures and the Price of Farmland in Metro Vancouver.

Ives, C. D., \& Kendal, D. (2013). Values and attitudes of the urban public towards peri-urban agricultural land. Land Use Policy, 34, 80-90.

Jackson-Smith, D., Clark, J., Sharp, J., \& Inwood, S. (2008). Local Agency and Trajectories of Agricultural Change at the Rural-Urban Interface in the United States. Paper presented at the Transitions in Urban Agriculture Conference, at Wageningen, Netherlands.

Macdonald, S., \& Keil, R. (2012). The Ontario greenbelt: Shifting the scales of the sustainability fix? The Professional Geographer, 64(1), 125-145.

Marsden, T. (2013). Sustainable place-making for sustainability science: the contested case of agri-food and urban-rural relations. Sustainability Science, 8(2), 213-226.

Nabhan, G. P. (2009). Coming home to eat: The pleasures and politics of local food: WW Norton \& Company.

Newman, L. (2017). Speaking in Cod Tongues: A Canadian Culinary Journey. Regina: University of Regina Press.

Newman, L., Powell, L. J., \& Wittman, H. (2015). Landscapes of food production in agriburbia: Farmland protection and local food movements in British Columbia. Journal of Rural Studies, 39, 99-110. 
Nixon, D. V., \& Newman, L. (2016). The efficacy and politics of farmland preservation through land use regulation: Changes in southwest British Columbia's Agricultural Land Reserve. Land Use Policy, 59, 227-240.

Park, T., Mishra, A. K., \& Wozniak, S. J. (2014). Do farm operators benefit from direct to consumer marketing strategies? Agricultural Economics, 45(2), 213-224.

Powell, L. J., \& Engelhardt, E. S. (2015). The Perilous Whiteness of Pumpkins. GeoHumanities, $1(2), 414-432$.

Sandul, P. J. (2010). The agriburb: Recalling the suburban side of ontario, california's agricultural colonization. Agricultural History, 195-223.

Schilling, B. J., Sullivan, K. P., \& Komar, S. J. (2012). Examining the economic benefits of agritourism: the case of New Jersey. Journal of Agriculture, Food Systems and Community Development, 3(1), 199-214.

Smith, A., \& MacKinnon, J. B. (2009). The 100-mile diet: A year of local eating. Vintage Canada.

Soja, E. W. (1980). The socio-spatial dialectic. Annals of the Association of American Geographers, 70(2), 207-225.

Stake, R. E. (2005). Qualitative case studies. In N. K. Denzin \& Y. S. Lincoln (Eds.), The Sage handbook of qualitative research, 3rd ed. (pp. 443-466). Thousand Oaks, CA: Sage Publications Ltd.

Stobbe, T., Cotteleer, G., \& Van Kooten, G. (2009). Hobby farms and protection of farmland in British Columbia. Canadian Journal of Regional Science, 32(3), 393.

Stobbe, T., Eagle, A. J., \& Van Kooten, G. (2010). Niche and Direct Marketing in the RuralUrban Fringe: A Study of the Agricultural Economy in the Lower Mainland and Fraser Valley. BC Studies(167), 105.

Talbot, M. (2012). Farm Diversification and Farm Tourism in Wales: The experience of entrepreneurial farmers. Regions Magazine, 285(1), 22-25.

Tew, C., \& Barbieri, C. (2012). The perceived benefits of agritourism: The provider's perspective. Tourism Management, 33(1), 215-224.

Tippins, M. J., Rassuli, K. M., \& Hollander, S. C. (2002). An assessment of direct farm-to-table food marketing in the USA. International Journal of Retail \& Distribution Management, 30(7), 343-353.

Von Thünen, J. H., \& Hall, P. G. (1966). Isolated state. Pergamon.

Zasada, I. (2011). Multifunctional peri-urban agriculture-A review of societal demands and the provision of goods and services by farming. Land use policy, 28(4), 639-648. 